\title{
Karakteristik Dangke Susu Kerbau dengan Penambahan Crude Papain Kering
}

\author{
Characteristics of Dangke Derived from Buffalo Milk with Addition of Dry Crude Papain
}

\author{
S. Sulmiyati ${ }^{*}$, Nur Saidah Said ${ }^{1}$ \\ ${ }^{1}$ Program Studi Peternakan, Fakultas Peternakan dan Perikanan, Universitas Sulawesi Barat, \\ Jl. Prof. Dr. Baharuddin Lopa, SH. Talamung, Majene, 91413, Indonesia \\ *Email: sulmiyati@unsulbar.ac.id
}

Tanggal submisi: 25 April 2017; Tanggal penerimaan: 31 Agustus 2018

\begin{abstract}
ABSTRAK
Dangke adalah makanan khas Enrekang, Sulawesi Selatan yang terbuat dari penggumpalan protein susu kerbau atau susu sapi dengan menggunakan getah pepaya. Informasi mengenai karakteristik dangke susu kerbau masih terbatas dibandingkan dengan dangke berbahan dasar susu sapi. Karakteristik dangke dipengaruhi oleh level getah pepaya yang diberikan. Penelitian ini bertujuan untuk mengetahui pengaruh penambahan crude papain terhadap produksi curd dangke, persentase whey, pH, persentase asam laktat dan organoleptik dangke susu kerbau. Penelitian ini menggunakan Rancangan Acak Lengkap (RAL) dengan 4 perlakuan dan 5 ulangan. Perlakuan penambahan crude papain dengan level berbeda $0,5 \% ; 1 \% ; 1,5 \%$ dan $2,0 \%$. Hasil penelitian menunjukkan bahwa produksi curd dangke yang dihasilkan sekitar 37,04-52,88\%, persentase whey yang dihasilkan 41,38-52,32, pH 6,92-6,96, persentase asam laktat 0,15-0,17 dan warna curd dangke 1,35 (putih)-1,50 (putih), bau 2,50 (agak beraroma dangke)-3,55 (agak beraroma dangke), rasa dangke yang dihasilkan 2,10 (pahit)-4,60 (tidak pahit) dan tingkat kesukaan 2,00 (tidak suka)-3,90 (suka). Hasil penelitian bahwa dangke susu kerbau yang terbaik pada perlakuan dengan penambahan crude papain sebanyak $1 \%$. Karakteristik fisiokimia dangke yang dihasilkan, yakni produksi curd dangke 43,94\%; persentase Way 51,14; pH 6,96; dan persentase asam laktat 0,15. Karakteristik organoleptik warna curd dangke 1,45 (putih); bau 2,55 (agak beraroma dangke/susu); rasa 4,10 (cukup pahit) dan tingkat kesukaan 3,55 (suka).
\end{abstract}

Kata kunci: Susu kerbau; crude papain, dangke; Enrekang

\begin{abstract}
Dangke is traditional food from Enrekang, South Sulawesi, which is made from coagulated buffalo milk or cow milk protein by using crude papain. There is limited information about characteristics of dangke from buffalo milk than those from cow milk. The characteristics of dangke is affected by the addition of crude papain. This study was aimed to explore the effect of crude papain addition to curd dangke production, percentage of whey, $\mathrm{pH}$, percentage of lactic acid and organoleptic of dangke from buffalo milk. This study was conducted by using complete randomized design with 4 treatments and 5 repetitions. Treatments consist of the addition of crude papain in different concentration: $0.5 \% ; 1 \% ; 1.5 \%$ and $2.0 \%$. This study howed that curd dangke production range bas 41.38- 52.20; $\mathrm{pH}$ range was 6.92- 6.96; lactic acid percentage range is $0.15-0.70$; curd dangke's colour range was 1.35 (white)- 1.50 (white); smell range was 2.50 (mild dangke' smell)- 3.55 (mild dangke' smell); taste range was 2.10 (bitter)- 4.60 (not bitter) and preference level range was 2.00 (dislike)- 3.90 (like). This study revealed that the best quality of dangke from buffalo milk was derived from treatments with addition of $1 \%$ crude papain. Physicochemistry characteristics from our dangke: curd dangke production was $43.94 \%$; whey percentage was 51.14; pH was 6.96; lactic acid percentage was 0.15. Organoleptic characteristics: curd dangke's colour was 1.45 (white), smell was 2.55 (mild dangke' smell), taste was 4.10 (slightly bitter) and preference level was 3.55 (like).
\end{abstract}

Keywords: Buffalo milk; crude papain; dangke, Enrekang

DOI: http://doi.org/10.22146/agritech.24331

ISSN 0216-0455 (Print), ISSN 2527-3825 (Online) 


\section{PENDAHULUAN}

Dangke merupakan produk olahan susu dan makanan khas dari daerah Enrekang, Sulawesi Selatan. Dangke dikelompokkan ke dalam jenis keju lunak (soft cheese) yang terbuat dari penggumpalan susu dengan menggunakan enzim papain yang diperoleh dari getah buah pepaya. Pengunaan larutan getah pepaya oleh masyarakat di Kabupaten Enrekang masih dilakukan secara tradisional dan belum ada standarisasi dalam penggunaan konsentrasi getah pepaya. Sehingga berimplikasi terhadap beragamnya kualitas dangke yang dihasilkan. Selain itu, produk dangke yang pada mulanya terbuat dari susu kerbau mulai tergeser dengan produk dangke yang terbuat dari susu sapi.

Proses pembuatan dangke oleh masyarakat Enrekang umumnya dilakukan melalui pemanasan susu kemudian ditambahkan getah pepaya, setelah terjadi penggumpalan kemudian dilakukan penyaringan dengan menggunakan tempurung kelapa yang sekaligus sebagai alat pencetak dangke dan selanjutnya dibungkus dengan daun pisang. Bentuk dangke dan pembungkus daun pisang menjadi ciri khas dari produk dangke oleh masyarakat Enrekang. Menurut Malaka dkk. (2015), bahwa struktur dangke yang terbaik pada pemanasan $75{ }^{\circ} \mathrm{C}$ dengan konsentrasi getah pepaya $0,5 \%$ memiliki kandungan protein $17,94 \%$, lemak $24,295 \%$, laktosa $14,12 \%$, pH 5,93 dan persentase asam laktat 0,296\%. Mukhlisah dkk. (2017)melaporkan bahwa dangke yang memiliki kualitas terbaik pada suhu pemansan $80^{\circ} \mathrm{C}$ dan konsentrasi papain 0,3\%. Karakteristik dangke yang dihasilkan memiliki kadar protein 16,86\%; air 58,75\%; lemak 15,19\%; abu 2,31\%; karbohidrat 5,88\%. Karakteristik fisik dangke yang dihasilkan meliputi $\mathrm{pH}$ 6,62 ; produksi curddangke $15,66 \%$ dan kekerasan 7529 gf). Sabil dkk. (2017), berpendapat bahwa suhu pemeraman memberikan pengaruh terhadap kualitas kimia dan mikrostruktur dangke berbahan dasar susu sapi, dimana pada suhu pemeraman $5^{\circ} \mathrm{C}$ memiliki kadar protein $24,98 \%$, lemak 2,26\%, dan kadar air 51,15\%.

Berbagai produk keju traditional yang menjadi makanan khas suatu daerah seperti Keju Iranian Brine (Najafi dkk., 2008); keju Cimi tulum, Turkey (Karagozlu dkk., 2009), keju Ras, Mesir (Ismail, 2011); keju Nabulsi, Eropa Selatan (Mazahreh dkk., 2009); (Alrus dkk., 2009); keju Braided (Celebi dan Simsek, 2015); keju Sepet, Turkey (Ercan, 2009), dan keju Ras (AbuZeid, 2015).

Penggumpalan susu dengan menggunakan getah pepaya sangat dipengaruhi oleh konsentrasi getah pepaya yang ditambahkan. Penelitian yang dilakukan oleh Sulmiyati dan Malaka (2017), bahwa crude papain dengan pengenceran $10^{-2}$ pada konsentrasi $1 \%$ (v/v) memberikan hasil yang terbaik pada produksi curd dangke susu sapi. Produksi curddangke yang dihasilkan sebanyak $13,08 \%$ dengan persentase whey $86,92 \%$. Beberapa penelitian terkait level penggunaan getah pepaya pada dangke berbahan dasar susu sapi diantaranya meliputi Fatma dkk. (2012) dengan level enzim papain 0,8\%, Malaka dkk. (2015) penggunaan enzim papain 0,5\%, dan Yuniwati dkk. (2008) dengan enzim papain $0,4 \%$. Oleh sebab itu, penelitian ini bertujuan untuk mengetahui kualitas dangke susu kerbau terhadap produksi curd dangke dan persentase whey dengan penambahan getah pepaya pada level yang berbeda sebagai dasar dalam standarisasi penggunaan larutan enzim papain (crude papain) sebagai bahan koagulan.

\section{METODE PENELITIAN}

\section{Bahan dan Alat}

Bahan yang digunakan dalam penelitian ini adalah buah pepaya umur 2-3 bulan yang dikumpulkan dari petani Kabupaten Bantaeng, Sulawesi Selatan. Susu kerbau diperoleh di Curio, Kabupaten Enrekang. Alat yang digunakan meliputi timbangan analitik (cis BC600), freeze dryer Alpha 1-2 LD (christ), Penangas air (cimarec 3), mikropipet (pipetman p-1000), pH meter (Hanna), vortex mixer.

\section{Pengeringan Crude Papain}

Penelitian ini dilaksanakan di Laboratorium Teknologi Pengolahan Susu, Fakultas Peternakan Universitas Hasanuddin, Makassar. Getah pepaya yang digunakan diperoleh dari penyadapan buah pepaya mentah kemudian dikeringkan dengan freeze dryer suhu $-45{ }^{\circ} \mathrm{C}$ selama 50 jam.

\section{Pembuatan Dangke}

Pemanasan susu kerbau dengan metode HTST (high temperature short time) pada suhu $75^{\circ} \mathrm{C}$ selama 15 detik, kemudian ditambahkan papain kasar yang sudah diencerkan dengan pengenceran $10^{-2}$ pada level $0,5 \% ; 1 \% ; 1,5 \%$; dan $2 \%(\mathrm{v} / \mathrm{v})$. Curd dengan whey dipisahkan dengan menggunakan saringan teh sambil ditekan dan didiamkan beberapa menit sampai whey

Tabel 1. Bahan baku dan formula pembuatan dangke susu kerbau

\begin{tabular}{ll}
\hline \multicolumn{1}{c}{ Bahan } & \multicolumn{1}{c}{ Kuantitas } \\
\hline Susu kerbau & $500 \mathrm{~mL}$ \\
Getah papaya & $0,5 \% ; 1 \% ; 1,5 \% ; 2 \%$ \\
\hline
\end{tabular}


tidak menetes lagi. Konsentrasi getah pepaya yang digunakan merupakan rujukan dari penelitian Sulmiyati (2010). Bahan dan formula yang digunakan dalam pembuatan dangke sebagaimana tertera pada Tabel 1 .

\section{Pengukuran Produksi Curd Dangke, Persentase whey, pH dan Persentase Asam Laktat}

Parameter yang diukur adalah produksi curddangke (Persamaan 1) dan persentase whey (Persamaan 2), pengukuran $\mathrm{pH}$ dangke (Hadiwiyoto, 1994), dan persentase asam laktat (Hadiwiyoto, 1994) (Persamaan 3)

Produksicurd $(\%)=\frac{\text { Beratcurd }}{\text { Volume susu awal }} \times 100 \%$

Persentase whey $(\%)=\frac{\text { Volume whey }}{\text { Volume susu awal }} \times 100 \%$

Persentase asam laktat $(\%)=\frac{\mathrm{mL} \mathrm{NaOH} \times 0,009 \times 100 \%}{\text { Berat susu }(\mathrm{g})}$

\section{Pengujian Organoleptik Rasa Dangke}

Pengujian kualitas organoleptik dangke untuk mengetahui batasan penggunaan crude papain dari rasa pahit. Kualitas organoleptik dengan menggunakan 20 orang panelis semi terlatih yang sudah mengenal dangke. Kriteria penilaian yang diuji berupa warna, bau, rasa, dan kesukaan dapat dilihat pada Tabel 2.

\section{Analisis Data}

Data penelitian yang diperoleh dianalisis dengan menggunakan software analysis of variance (ANOVA) dan apabila terdapat pengaruh yang nyata pada setiap perlakuan dilanjutkan dengan uji beda nyata terkecil (BNT) pada tingkat ketelitian 0,05 (Steel dan Torrie, 1993).

\section{HASIL DAN PEMBAHASAN}

\section{Pengaruh Level Crude Papain terhadap Produksi Curd Dangke}

Rataan produksi curd dangke yang dihasilkan dengan penambahan crude papain kasar $\left(10^{-2}\right)$ pada level berbeda dapat dilihat Gambar 1 .

Produksi curd dangke yang dihasilkan semakin tinggi seiring dengan tingkat penambahan crude papain. Hasil penelitian diperoleh nilai produksi curd dangke sekitar 37,04-52,88\%, dimana penambahan crude papain konsentrasi $2 \%(\mathrm{v} / \mathrm{v})$ menghasilkan produksi curd dangke tertinggi yaitu 52,88\% dan produksi curd dangke yang terendah pada level pemberian crude papain $0,5 \%$ adalah 37,04\%. Nilai produksi curd yang dihasilkan pada setiap perlakuan penambahan crude papain dengan konsentrasi $0,5 \%, 1,0 \%, 1,5 \%$ dan $2 \%$ masingmasing berturut-turut 37,04\%, 43,94\%; 45,68\%, dan $52,88 \%$. Hasil analisis ragam bahwa pemberian level crude papain tidak memberikan pengaruh yang nyata $(p<0,05)$ terhadap produksi curd. Produksi curd dangke yang dihasilkan lebih tinggi dibandingkan produksi curd dangke yang dihasilkan oleh Sulmiyati dan Malaka (2017), pada susu sapi yang menghasilkan produksi curd dangke sebanyak $11,75 \%$ dengan level crude papain 0,5\% (v/v). Lebih lanjut menurut Fatma (2012),

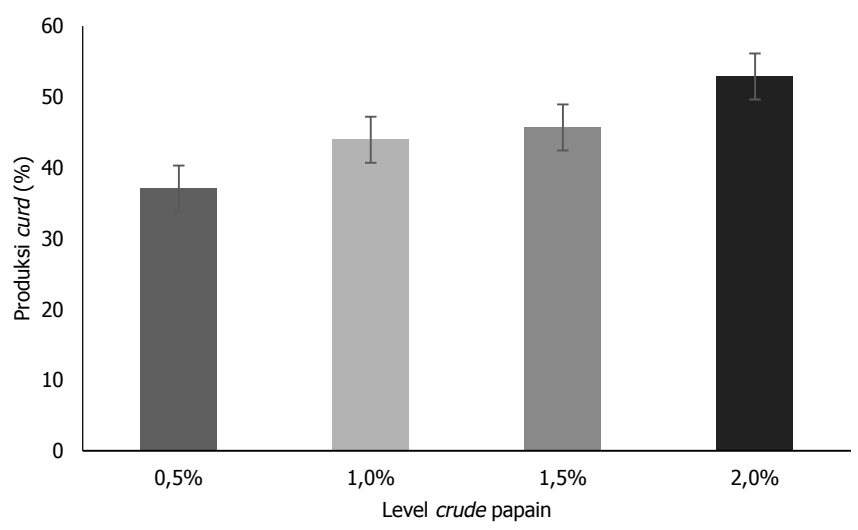

Gambar 1. Pengaruh penambahan crude papain kasar dengan konsentrasi berbeda terhadap produksi curd dangke (\%)

Tabel 2. Indikator penilaian warna, bau, rasa, dan kesukaan dangke susu kerbau

\begin{tabular}{|c|c|c|c|c|c|}
\hline \multirow[t]{2}{*}{ Parameter } & \multicolumn{5}{|l|}{ Indikator penilaian } \\
\hline & 1 & 2 & 3 & 4 & 5 \\
\hline Warna & Sangat kuning & Kuning & Agak kuning & Putih & Sangat putih \\
\hline Bau/aroma & $\begin{array}{l}\text { Tidak beraroma } \\
\text { dangke }\end{array}$ & $\begin{array}{l}\text { Sedikit beraroma } \\
\text { dangke }\end{array}$ & $\begin{array}{l}\text { Agak beraroma } \\
\text { dangke }\end{array}$ & Beraroma dangke & $\begin{array}{l}\text { Sangat beraroma } \\
\text { dangke }\end{array}$ \\
\hline Rasa & Sangat pahit & Pahit & Agak pahit & Cukup pahit & Tidak pahit \\
\hline Kesukaan & Sangat tidak suka & Tidak suka & Agak suka & Suka & Sangat suka \\
\hline
\end{tabular}


bahwa nilai rendemen curd dangke yang dihasilkan dengan penambahan level enzim sebanyak 0,8\% (v/v) menghasilkan nilai rendemen curd dangke yang terbaik yaitu $10,55 \pm 0,1 \%$ (b/b).

Curd dangke yang dihasilkan pada susu kerbau lebih tinggi dibandingkan dengan produksi curd dangke yang dihasilkan dari susu sapi dengan level crude papain yang sama. Hal ini disebabkan kandungan atau total padatan susu kerbau lebih tinggi dibandingkan susu sapi, kandungan lemak memberikan pengaruh terhadap produksi curd dangke yang dihasilkan. Menurut Hogberg dan Lind (2003) sejalan dengan Hasinah dan Handiwirawan (2007), bahwa perbedaan terbesar komposisi susu kerbau dan sapi adalah pada kandungan lemak, susu sapi kandungan lemak antara 3-5\%, sedangkan susu kerbau kandungan lemak berkisar antara $7-12 \%$ tetapi bisa juga mencapai $13 \%$. Sementara itu, kandungan protein, laktosa dan abu agak lebih tinggi pada susu kerbau dibandingkan susu sapi. Hal ini sejalan dengan penelitian Arlene dkk. (2015), yang menunjukkan bahwa produksi curd dangke tertinggi diperoleh dari penambahan papain menggunakan susu kambing dibandingkan susu sapi dan susu kedelai. Produksi curd dangke yang dihasilkan dengan menggunakan susu kambing 10,35\% lebih tinggi dibandingkan susu sapi 9,35\% dan susu kedelai 4,39\%. Curd yang dihasilkan dipengaruhi oleh kandungan lemak yang terdapat dalam susu yang digunakan, semakin tinggi lemak yang terkandung sejalan dengan produksi curd pada keju cheddar. Verdier-Metz dkk. (2001), bahwa kandungan protein dan lemak pada susu memiliki hubungan dalam produksi curd yang dihasilkan. Hasil yang diperoleh Bhattarai and Acharya (2010), menunjukkan bahwa produksi curd dangke dalam pembuatan keju mozzarella menggunakan susu sapi lebih tinggi $(11,45 \%)$ dibandingkan dengan susu kerbau $(10,71 \%)$.

Curd yang terbentuk juga dipengaruhi oleh aktivitas enzim papain yang diberikan. Aktivitas enzim papain pada pembuatan keju/dangke sangat dipengaruhi oleh banyaknya enzim papain yang diberikan. Menurut Nurhidayati (2003), bahwa enzim papain bekerja secara optimal tergantung dari konsentrasi enzim yang diberikan. Sukendar (2001) menegaskan bahwa yang memberikan pengaruh terhadap aktivitas enzim adalah konsentrasi enzim, konsentrasi substrat, dan konsentrasi ionik dan suhu. Hasil penelitian Najafidkk. (2008), produksi curd meningkat sejalan dengan penambahan starter dan $\mathrm{pH}$ renet yang diberikan. Produksi curd tinggi pada penambahan starter $3 \%$ dengan renet pada pH 6.

\section{Pengaruh Level Crude Papain terhadap Persentase Whey}

Rataan persentase whey yang dihasilkan dengan penambahan crude papain kasar $\left(10^{-2}\right)$ dengan level berbeda dapat dilihat pada Gambar 2.

Persentase whey yang dihasilkan pada penelitian ini sekitar $41,38-52,32$. Pada level crude papain $2 \%$ $(\mathrm{v} / \mathrm{v})$ menghasilkan persentase whey terendah yaitu 41,38 , sedangkan persentase whey tertinggi terdapat pada keju dengan level $0,5 \%$ yaitu 52,32. Nilai Persentase whey yang dihasilkan pada setiap perlakuan penambahan crude papain dengan konsentrasi $0,5 \%$, $1,0 \%, 1,5 \%$, dan $2 \%$ masing-masing berturut-turut $52,32,51,14,46,9$ dan 41,38. Hasil analisis ragam bahwa pemberian level crude papain tidak memberikan pengaruh yang nyata $(p>0,05)$ terhadap persentase whey yang dihasilkan akan tetapi menghasilkan banyak curd yang terbentuk maka whey yang tersisa semakin sedikit sejalan dengan level crude papain yang diberikan. Hal tersebut memperlihatkan bahwa semakin banyak curd yang terbentuk maka whey yang tersisa semakin rendah. Sulmiyati dan Malaka (2017) melaporkan bahwa larutan enzim papain $1 \%$ pada konsentrasi $0,5 \%(\mathrm{v} / \mathrm{v})$ menghasilkan persentase whey yang lebih tinggi yaitu sekitar 88,24. Konsentrasi1,5\% ( $/ \mathrm{v}$ ) menghasilkan persentase whey lebih rendah yaitu sekitar 86,92. Hal ini menunjukkan bahwa semakin banyak curd yang dihasilkan sejalan dengan penurunan jumlah whey. Berdasarkan data tersebut bahwa persentase whey yang dihasilkan pada dangke susu kerbau lebih sedikit dibandingkan persentase whey yang dihasilkan pada susu sapi. Mateo dkk. (2009)menyatakan bahwa volume whey yang dihasilkan menurun sejalan dengan meningkatnya konsentrasi lemak pada susu.

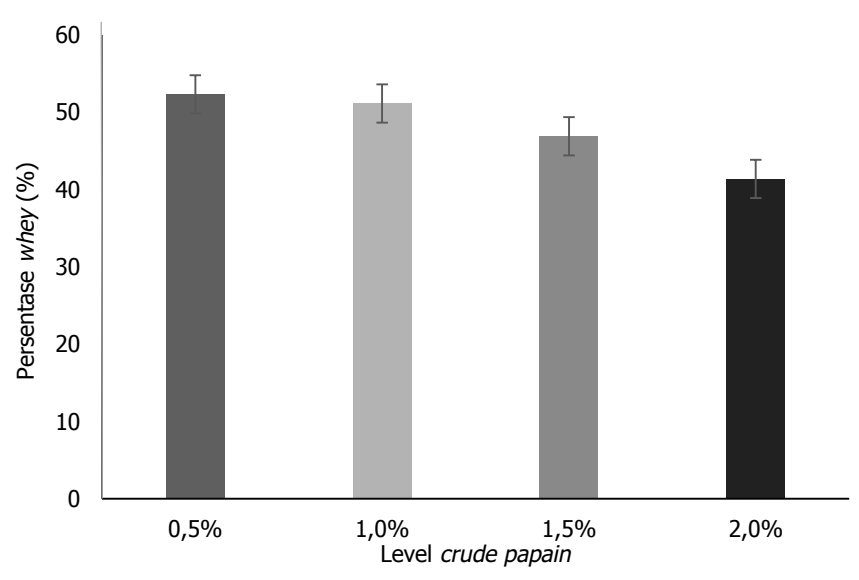

Gambar 2. Pengaruh penambahan crude papain kasar dengan level berbeda terhadap persentase whey 


\section{Pengaruh Level Crude Papain terhadap Potential of Hidrogen (pH)}

Hasil penelitian yang diperoleh terhadap $\mathrm{pH}$ curd dangke yang dihasilkan sekitar 6,92-6,96 (Gambar 3). Nilai pH curd dangke yang dihasilkan pada setiap perlakuan penambahan crude papain dengan konsentrasi $0,5 \%, 1,0 \%, 1,5 \%$ dan $2 \%$ masing-masing berturut-turut $6,92,5,96,6,94$, dan 6,94. Berdasarkan hasil analisis ragam bahwa penambahan crude papain tidak berpengaruh nyata $(p>0,05)$ terhadap $\mathrm{pH}$ curd dangke susu kerbau. Hal ini karena $\mathrm{pH}$ tergantung dari $\mathrm{pH}$ susu kerbau yang digunakan sekitar antara 6,7-6,9. $\mathrm{pH}$ susu kerbau ini tinggi dibandingkan menurut NRC (1981), pH susu kerbau 6,7 tetapi menurut Pelegrine (2014) bahwa pH susu kerbau sekitar 6,89. Hal ini disebabkan oleh selama pengangkutan susu kerbau mengalami pembekuan untuk mencegah kerusakan pada susu kerbau sehingga memberikan pengaruh terhadap perubahan $\mathrm{pH}$ susu kerbau menjadi tinggi. $\mathrm{pH}$ curd dangke yang dihasilkan tertinggi dibandingkan dengan Sameen dkk. (2010) yang memiliki nilai pH keju mozarella yang terbuat dari susu kerbau 6,62-6,63. Menurut Hatta dkk. (2013), pH dangke susu kerbau sekitar 6,2-6,5.

\section{Pengaruh Level Crude Papain terhadap Persentase Asam Laktat}

Hasil penelitian yang diperoleh terhadap persentase asam laktat dangke yang dihasilkan sekitar 0,15-0,17 (Gambar 4). Nilai Persentase whey yang dihasilkan pada setiap perlakuan penambahan crude papain dengan konsentrasi $0,5 \%, 1,0 \%, 1,5 \%$, dan $2 \%$ masing-masing berturut-turut $0,17,0,15,0,16$ dan 0,16 . Berdasarkan hasil analisis ragam bahwa penambahan crude papain tidak berpengaruh nyata $(p>0,05)$ terhadap persentase asam laktat dangke susu kerbau. Hal ini karena persentase asam laktat tergantung persentase asam laktat pada susu kerbau. Bahwa persentase asam laktat susu kerbau yang digunakan sekitar 0,15-0,18. Persentase asam laktat yang dihasilkan lebih tinggi dibandingkan Sameen dkk. (2010), bahwa persentase keasaman keju mozarella yang terbuat dari susu kerbau sekitar 0,13-0,14.

\section{Kualitas Organoleptik Dangke Susu Kerbau}

Rataan nilai organoleptik dangke susu kerbau dengan penambahan crude papain kasar $\left(10^{-2}\right)$ dengan level berbeda terhadap rasa dangke dapat dilihat pada Tabel 3.

Kualitas organoleptik dari penelitian ini terlihat bahwa warna dangke yang dihasilkan tidak memberikan pengaruh yang nyata $(p>0,05)$ terhadap warna

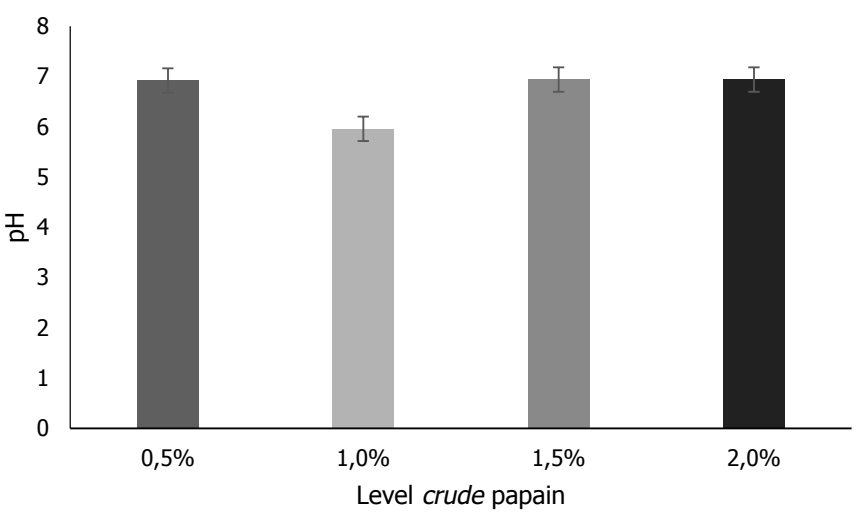

Gambar 3. Pengaruh penambahan crude papain kasar dengan level berbeda terhadap $\mathrm{pH}$ curd dangke

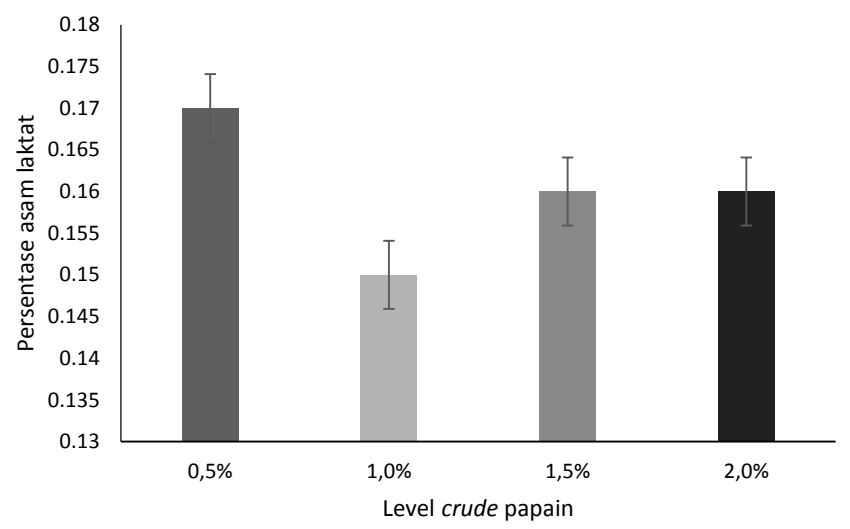

Gambar 4. Pengaruh penambahan crude papain kasar dengan level berbeda terhadap persentase asam laktat

dangke yang dihasilkan. Warna dangke yang dihasilkan tergantung dari warna susu yang digunakan. Warna dangke tetap putih karena pada penelitian ini proses pasteurisasi susu kerbau menggunakan metode bath sehingga tidak menyebabkan perubahan warna susu atau karamelisasi akibat pemanasan susu. Warna dangke yang dihasilkan Tabel 3. berkisar antara 1,35 (putih)-1,50 (putih). Hasil penelitian Hatta dkk. (2013) menunjukkan bahwa warna dangke susu kerbau yang dibuat oleh masyarakat Enrekang 63,9\% putih kekuningan, 16,7\% putih keabuan dan 19,4\% putih. Hasil warna dangke yang diperoleh di Enrekang berbeda dengan yang dihasilkan pada penelitian ini dimana rata-rata warna dangke yang dihasilkan putih. Karena masyarakat Enrekang dalam membuat dangke melakukan pemanasan susu tanpa menggunakan metode bath sehingga akan memberikan pengaruh terhadap perubahan warna susu akibat pemanasan tinggi.

Bau yang dihasilkan pada penelitian ini adalah khas dangke, tidak ada pengaruh yang nyata $(p>0,05)$ terhadap bau dangke yang dihasilkan dari level penambahan crude papain dengan bau susu yang 
digunakan. Tabel 3 menunjukkan bahwa dengan penambahan crude papain tidak memberikan pengaruh terhadap bau dangke yang dihasilkan. Bau dangke yang dominan adalah bau susu, masing-masing bau dangke pada level crude papain $0,5 \% ; 1 \% ; 1,5 \%$, dan $2 \%$ masing-masing 3,55 (agak beraroma dangke), 2,55 (agak beraroma dangke), 2,70 (agak bearoma dangke), 2,50 (agak beraroma dangke). Menurut Malaka dan Sulmiyati (2010), bahwa keju markisa memberikan pengaruh yang nyata $(p<0,05)$ terhadap bau keju yang dihasilkan. Penambahan sari markisa selain memberikan pengaruh terhadap perubahan warna keju, juga memberikan pengaruh terhadap bau keju yang dihasilkan masing-masing berbau khas susu dan markisa pada setiap level starter yang digunakan 0,5\%; $1 \%$; dan $1,5 \%$ dengan nilai proporsi bau keju masingmasing 2,$62 ; 2,68 ; 2,81$.

Rasa dangke yang dihasilkan pada penelitian ini dipengaruhi secara nyata $(p<0,05)$ oleh penambahan level crude papain yang diberikan, dimana semakin tinggi level crude papain akan memberikan rasa pahit pada dangke. Rasa pahit yang dihasilkan pada penelitian ini sekitar antara 2,10 (pahit)-4,60 (tidak pahit). Rasa pahit mulai terasa pada level $1 \%$, nilai rasa yang diperoleh 4,10 (cukup pahit), level 0,5\% crude papain tidak memiliki rasa pahit dengan nilai rasa yang dihasilkan 4,60 (tidak pahit), dan rasa pahit sangat terasa di level crude papain 1,5\%-2\% masingmasing nilai organoleptik rasa 3,15 (agak pahit) dan 2,10 (pahit). Hasil yang diperolehdisimpulkan bahwa penggunaan crude papain pada konsentrasi $0,5 \%-1 \%$ $(\mathrm{v} / \mathrm{v})$ menghasilkan rasa organoleptik tidak pahit. Djide (1991) berpendapat bahwa penambahan crude papain yang berlebihan menyebabkan dangke terasa pahit. Oleh karena itu, rasa pahit pada dangke menjadi dasar dalam penentuan level crude papain yang digunakan disamping untuk menstandarisasikan dangke dengan kualitas yang tetap.

Tingkat kesukaan dangke susu kerbau level crude papain 0,5\% lebih tinggi sekitar 3,90 (suka) dibandingkan dangke pemberian level crude papain $2 \%$ dimana ratarata panelis memberikan nilai 2,00 (tidak suka). Tingkat kesukaan panelis terhadap dangke level crude papain $0,5 \% ; 1 \% ; 1,5 \%$ dan $2 \%$ (Tabel 3) masing-masing 3,90 (suka); 3,55 (suka), 2,60 (agak suka) dan 2,00 (tidak suka). Tingkat kesukaan panelis sangat dipengaruhi oleh rasa pahit yang terdapat pada dangke. Rasa pahit ini dipengaruhi oleh level crude papain yang diberikan. Oleh sebab itu, dangke dengan tingkat kesukaan tinggi terdapat pada dangke level crude papain 0,5-1\%.

\section{KESIMPULAN DAN SARAN}

Karakteristik dangke yang terbaik berdasarkan karakteristik fisik dan organoleptik terdapat pada penambahan crude papain $1 \%$ dengan produksi curd 43,94\%, persentase Way 51,14, pH 6,96; persentase asam laktat 0,15 . Karakteristik organoleptik dangke dengan level crude papain $1 \%$ memiliki skor warna 1,45 (putih); bau 2,55 (agak beraroma dangke/susu); rasa 4,10 (cukup pahit) dan tingkat kesukaan 3,55 (suka).

\section{UCAPAN TERIMA KASIH}

Penelitian ini bisa terlaksana adanya dukungan dana dari Direktorat Riset dan Pengabdian Kepada Masyarakat Direktorat Jenderal Penguatan Riset dan Pengembangan Kementerian Riset, Teknologi dan Pendidikan TinggiTahun 2017 skema Hibah Penelitian

Tabel 3. Rataan \pm SD parameter kualitas dangke susu kerbau dengan crude papain kasar $\left(10^{-2}\right)$ dengan level berbeda

\begin{tabular}{|c|c|c|c|c|}
\hline Parameter & Level crude papain & & & \\
\hline & $0,5 \%$ & $1 \%$ & $1,5 \%$ & $2 \%$ \\
\hline Warna & $\begin{array}{l}1,50 \pm 0,51^{a} \\
\text { Putih }\end{array}$ & $\begin{array}{l}1,45 \pm 0,68^{a} \\
\text { Putih }\end{array}$ & $\begin{array}{l}1,40 \pm 0,50 \text { a } \\
\text { Putih }\end{array}$ & $\begin{array}{l}1,35 \pm 0,48^{a} \\
\text { Putih }\end{array}$ \\
\hline Bau & $\begin{array}{l}3,55 \pm 0,88^{a} \\
\text { Agak beraroma dangke }\end{array}$ & $\begin{array}{l}2,55 \pm 0,82^{\mathrm{bc}} \\
\text { Agak beraroma dangke }\end{array}$ & $\begin{array}{l}2,70 \pm 0,97^{\mathrm{abc}} \\
\text { Agak beraroma dangke }\end{array}$ & $\begin{array}{l}2,50 \pm 0,88^{c} \\
\text { Agak beraroma dangke }\end{array}$ \\
\hline Rasa & $\begin{array}{l}4,6 \pm 0,68^{a} \\
\text { Tidak Pahit }\end{array}$ & $\begin{array}{l}4,1 \pm 1,25^{a} \\
\text { Cukup Pahit }\end{array}$ & $\begin{array}{l}3,15 \pm 1,30^{\mathrm{b}} \\
\text { Agak Pahit }\end{array}$ & $\begin{array}{l}2,1 \pm 0,78^{c} \\
\text { Pahit }\end{array}$ \\
\hline Kesukaan & $\begin{array}{l}3,90 \pm 0,71^{a} \\
\text { Suka }\end{array}$ & $\begin{array}{l}3,55 \pm 0,99^{a} \\
\text { Suka }\end{array}$ & $\begin{array}{l}2,60 \pm 1,18^{b} \\
\text { Agak suka }\end{array}$ & $\begin{array}{l}2,00 \pm 0,56^{\mathrm{bc}} \\
\text { Tidak suka }\end{array}$ \\
\hline
\end{tabular}

Deskripsi organoleptik: Warna : (1) putih, (2) putih kekuningan, (3) agak kuning, (4) kuning, (5) sangat kuning Bau: (1) tidak beraroma dangke, (2) sedikit beraroma dangke, (3) agak beraroma dangke, (4) beraroma dangke, (5) sangat beraroma dangke. Rasa: (1) sangat pahit (2) pahit (3) agak pahit (4) cukup pahit (5) tidak pahit. Kesukaan: (1) sangat tidak suka, (2) tidak suka, (3) agak suka, (4) suka, (5) sangat suka. 
Dosen Pemula (Nomor. 103/SP2H/LT/DRPM/IV/2017). Terima kasih kepada LPPM dan PM Universitas Sulawesi Barat atas kerjasamanya, Universitas Hasanuddin atas penyediaan sarana dan prasarana laboratorium.

\section{DAFTAR PUSTAKA}

Abu-Zeid N.A. (2015). The use of plant enzymes for ripening acceleration of Ras Cheese. IIOABJ.6 (2).15-21.

Alrus, K.A., Mazahreh, A.S., Quasen, J.M., Hejazin, R.K., \& Elqudah, J.M. (2009). Effect of proteases on meltability and stretchability of Nabulsi cheese. American Journal of Applied Sciences. 4(3):173-178.

Amri, E., \& Mamboya, F. (2012). Papain. A plant enzyme of biological importance: a review. Am J Biochme Biotechnol. 8:99-104. doi:10.3844/ajbbsp.2012.99.104

Arlene, A., Kristijarti, A.P., \& Ardelia, I. (2015). The effects of types of milk (cow, goat, soya) and enzymes (renet, papain, bromelain) toward cheddar cheese production. Makara J. Technol. 19(1):31-37. DOI:10.7454/mst. v19i1.3028.

Bhattarai, R.R., dan Acharya, P.P. (2010). Preparation and quality evaluation of Mozzarella cheese from different milk sources. J. Food Sci Technol. Nepal. 6:94-101.DOI: 10.3126/jfstn.v6i0.8268.

Celebi, M., dan Simsek, B. (2015). Effect of different coagulant enzymes used on quality of traditional Orgu cheese (Braided cheese). Mljekarstvo. 65(1):57-65.https://doi. org/10.15567/mljekarstvo.2015.0108.

Djide, M.N. (1991). Analisa Mikrobiologi Dangke Asal Kabupaten Enrekang. Proceedings Fakutas MIPA Universitas Hasanuddin, Makassar.

Ercan, D. (2009). Quality characteristics of traditional Sepet cheese. Thesis. The graduated School of Engineering and Sciences of Izmir Institute of Technology.

Fatma., Soeparno., Nurliyani., Hidayat, C., \& Taufik, M. (2012). Karakteristik Whey Limbah Dangke dan Potensinya sebagai Produk Minuman dengan Menggunakan Lactobacillus acidophilus FNCC 0051. Jurnal Agritech, 32(4):352-361. https://doi.org/10.22146/agritech.9577.

Geantaresa, E., \& Supriyanti, F.M.T. (2010). Pemanfaatan Ekstrak Kasar Papain sebagai Koagulan pada Pembuatan Keju Cottage Menggunakan Bakteri. Jurnal Sains dan Teknologi Kimia 1(1):38-43.

Hadikesumandjaya (2003). Pengaruh Lama Pengeringan dan Jenis Kemasan terhadap Persentase Kadar Lemak dan Kadar Protein pada Dangke. Skripsi. Fakultas Peternakan Universitas Hasanuddin, Makassar.

Hadiwiyoto, S. (1994). Teori dan Prosedur Pengujian Mutu Susu dan Hasil Olahannya. Liberty, Yogyakarta.

Hasinah, H., \& Handiwirawan, E. (2007). Pemanfaatan Penciri Gen K-Kasein untuk Seleksi pada Sapi dan Kerbau.
Seminar dan Lokakarya Nasional Usaha Ternak Kerbau. Hal 132-138.

Hatta, W., Sudarwanto, F.M.T., Sudirman, I., \& Malaka R. (2013). Survei Potensi Dangke Susu Sapi Sebagai Alternatif Dangke Susu Kerbau di Kabupaten Enrekang, Sulawesi Selatan. JITP 3(1):40-50.

Hogberg, M.S., \& Lind, O. (2003). Milk Production of Buffalo. In: Buffalo Milk Production. http://www.milkproduction. com/Library/Articles/Buffalo_Milk_Production_ Chapter_5_Milk_production_of_the_buffalo.htm [2 Juli 2015].

Ismail, M.M. (2011). Effect of adding denatured whey proteins to cheese milk or cheese curd on some properties of Ras cheese. J. Food and Dairy Sci. 2(12):699-707.

Karagozlu, C., Kilic, S., \& Akbulut, N. (2009). Some characteristics of Cimi tulum cheese from producing goat milk. Bulg J. Agric Sci. 15(4):292-297.

Malaka, R., Baco, S., \& Prahesti, K. I. (2015). Karakteristik dan Mekanisme Gelatinasi Curd Dangke Melalui Analisis Fisiko Kimia dan Mikrostruktur. JITP.4 (2):56-62.

Malaka, R., \& Sulmiyati. (2010). Karakteristik Fisik dan Organoleptik Keju Markisa dengan Pemberian Level Starter (Lactococcus lactis subps. lactis 527) dengan Lama Pemeraman yang Berbeda. Prosiding Seminar Nasional Teknologi Peternakan dan Veteriner. halm. 825-831.

Masita, S. (2015). Pengaruh Konsentrasi Getah Pepaya Segar terhadap Kualitas Fisik Dangke Susu Kerbau dan Susu Sapi. Skripsi. Fakultas Peternakan Universitas Hasanuddin, Makassar.

Mateo, M.J., Everard, C.D., Fagan, C.C., O'Donnell, C.P., Castilli, M., Payne, F.A., \& O'Callaghan, D.J. (2008). Efferct of milk fat concentration and gel firmness on syneresis during curd stirring in cheese-making. International Dairy Journal. 19(4):264-268.http://citeseerx.ist.psu. edu/viewdoc/download?doi=10.1.1.661.8910\&rep=rep 1\&type=pdf

Mazahreh, A.S., Quasem, J.M., Shawabheh, A.F., \& Afareh, I.A. (2009). The effect of adjusting $\mathrm{pH}$ on strecthability and meltability to white Brined Nabulsi cheese. American Journal of Applied Sciences. 6(4):543-550.

Mukhlisah, A.N., Arief, I.I., \& Taufik, E. (2017). Physical, Microbial and Chemical Qualities of Dangke Produced by Different Temperatures and Papain Concentrations. Media Peternakan 4(1):63-70.DOI: https://doi. org/10.5398/medpet.2017.40.1.63

Najafi, M.N., Koocheki, A., \& Mahdizade, M. (2008). Studies on the effect of starter culture concentration and renneting $\mathrm{pH}$ on the Iranian Brine cheese yield. American-Brasian J. Agric and Environ Sci. 3(3):325-332.

NRC, (1981). The Water Buffalo:New Prospects for an Underutilized Animal. National Academic Press, Washington, DC. 
Nurhidayati, T. (2003). Pengaruh konsentrasi enzim papain dan suhu fermentasi terhadap kualitas keju cottage. KAPPA,4:13-17.

Pelegrine, D.H.G. (2014). Dairy products production with buffalo milk. International Journal of Applied Sciece and Technology. 4(3):14-19.

Ridwan M. (2005). Strategi Pengembangan "Dangke" sebagai Produk Unggulan Lokal di Kabupaten Enrekang Sulawesi Selatan. Tesis. Institut Pertanian Bogor, Bogor.

Sabil, S., Malaka, R., \& Maruddin, F. (2017). Chemical and Microstructure Characteristics of Dangke at Various of Temperature Ripened. International Journal of ChemTech Research. 10(7):611-615.

Sameen, A., Anjum, F.M., Huma, N., \& Nawa, H. (2010). Chemical coposition and sensory evaluation of mozzarella cheese: influence by milk sources, fat levels, starter culture and ripening period. J. Agri. Sci., 47(1):26-31.

Steel, R.G.D., dan Torrie, J.H. (1993). Prinsip dan Prosedur Statistika: Suatu Pendekatan Biometric. Alih bahasa: B. Sumantri. Gramedia Pustaka Utama, Jakarta

Sukendar, N. (2001). Pengaruh Enzim dalam Pengolahan Pangan. Makalah Kursus Singkat Aspek Mikrobiologi dalam Pengolahan Pangan dan Keamanan Pangan bagi Staf Akademik PTN-KTI (14-26 Mei 2001), Makassar.
Sulmiyati dan Malaka, R. (2017). Karakteristik Fisik dan Kimia Air Dadih (Whey) Dangke dengan Level Enzim Papain yang Berbeda. JITP. 5(2):102-106.

Sulmiyati (2010). Karakteristik Whey Dangke dan Pengujian secara In Vivo terhadap Kadar Kolesterol dan Profil Lipoprotein Darah Ayam Broiler. Thesis. Program Studi Sistem-Sistem Pertanian, Universitas Hasanuddin, Makassar.

Surono, I.S. (2015). Traditional Indonesian dairy foods. Review article. Asia Pac J Clin Nutr. 24(1):S26-S30. Doi:10.6133/ apjen.2015.24.s1.05.

Verdier-Metz, I., Coulon, J.B., \& Pradel, P. (2001). Relationship between milk fat and protein contents and cheese yield. Anim. Res. 50:365-371.

Yuniwati, M., Yusran., \& Rahmadany. (2008). Pemanfaatan Enzim Papain sebagai Bahan Penggumpal dalam Pembuatan. Seminar Nasional Aplikasi Sains dan Teknologi. I ${ }^{\text {ST }}$ AKPRIND, Yogyakarta. 